\title{
Penilaian Perkembangan Anak Usia 0-36 bulan menggunakan Metode Capute Scales
}

\author{
Martin Hertanto, Nahla Shihab, Maelissa P. Ririmasse, Nashrul Ihsan, Maulina Rachmasari, \\ M. Triadi Wijaya, Melyarna Putri, Rini Sekartini, Corrie Wawolumaja \\ Departemen Ilmu Kesehatan Anak FKUI-RSCM \\ Departemen Kedokteran Komunitas FKUI
}

\begin{abstract}
Latar belakang. Proses pertumbuhan dan perkembangan anak amatlah penting. Mengetahui secara dini gangguan perkembangan diharapkan dapat memberikan manfaat yang lebih baik. Berbagai metode untuk mendeteksi gangguan perkembangan pada anak, antara lain metode Capute Scales (CAT/CLAMS) adalah uji tapis spesifik menilai kemampuan komunikasi dan fungsi kognitif untuk anak berusia 0-36 bulan.

Tujuan. Mengetahui hubungan antara beberapa faktor risiko terjadinya gangguan perkembangan dengan status perkembangan anak usia 0-36 bulan.

Metode. Desain penelitian yang digunakan adalah potong lintang. Pemeriksaan dilakukan terhadap 75 anak di RW 03, Kelurahan Pulo Gadung menggunakan skrining CAT/CLAMS dan pertanyaan tersebut diajukan kepada ibu. Pengambilan sampel dilakukan secara purposive sampling.

Hasil. Diperoleh status perkembangan normal sebesar 84\%, suspek gangguan perkembangan 13,3\%, gangguan komunikasi 3\%, dan tidak ditemukan subjek yang mengalami retardasi mental. Sejumlah faktor risiko yang diteliti adalah jenis kelamin, pemberian ASI eksklusif, urutan anak, usia ibu saat hamil, pendidikan ibu atau pengasuh, jumlah anak, jumlah penghasilan keluarga dan bentuk keluarga. Secara statistik tidak ada faktor risiko yang bermakna.

Kesimpulan. Jenis kelamin laki-laki, tidak mendapat ASI eksklusif, ibu dengan tingkat pendidikan tinggi, jumlah anak lebih dari dua, bentuk keluarga inti mempunyai kecenderungan lebih besar menderita status perkembangan yang tidak normal. Namun tidak dapat dibuktikan hubungan bermakna secara statistik antara faktor-faktor yang diteliti dengan status perkembangan anak. (Sari Pediatri 2009;11(2):130-5).
\end{abstract}

Kata kunci: CAT/CLAMS, perkembangan anak, anak 0-36 bulan

Alamat korespondensi

DR. Dr. Rini Sekartini, Sp.A(K). Divisi Tumbuh Kembang Pediatri Sosial. Departemen Ilmu Kesehatan Anak FKUI-RSCM. Jl. Salemba no. 6, Jakarta 10430. Telepon: 021-3160622. Fax.:021-3913982

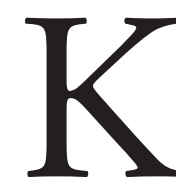

esehatan anak amat penting karena anak adalah masa depan bangsa dan negara. Anak memerlukan pertumbuhan dan pertume secara bersamaan. ${ }^{1}$ Pertumbuhan dihubungkan dengan bertambahnya jumlah dan besar sel tubuh dan dapat dilihat dari berat badan, tinggi badan, dan 
lingkar kepala. Perkembangan dihubungkan dengan meningkatnya fungsi sel tubuh yang mempunyai arti kualitas, yakni proses maturasi organ dan sistem, keterampilan, kemampuan afektif, intelegensi, dan kreativitas. Perkembangan fungsi susunan saraf pusat (SSP) merupakan kelanjutan pertumbuhan sel-sel neuron dan penyokong serta organ yang yang dipengaruhinya. Seluruh fungsi SSP tersebut penting dalam kehidupan manusia yang paripurna. ${ }^{2}$ Periode balita, terutama tiga tahun pertama merupakan tahap yang sangat penting karena pada masa tersebut terjadi pertumbuhan dan perkembangan sel-sel otak. ${ }^{1,3}$

Belum ada data prevalensi anak Indonesia yang mengalami gangguan perkembangan. Beberapa penelitian di Indonesia mendeteksi gangguan perkembangan anak pada usia pra sekolah 12,8\%28,5\%. ${ }^{4}$ Sebuah penelitian di Jakarta Barat menggunakan uji tapis Denver II menemukan 25\% populasi anak berusia 6 bulan- 3 tahun termasuk dalam kategori tersangka menderita gangguan perkembangan. ${ }^{4}$ Penelitian lain di Bandung dengan subjek bayi berusia 12-14 bulan dengan riwayat berat badan lahir rendah (BBLR) mendapatkan hasil 22,4\% mengalami tersangka gangguan perkembangan menurut uji tapis Denver II dan 17,6\% menurut Kuesioner Praskrining Perkembangan (KPSP). ${ }^{5}$

Beberapa metode dapat digunakan untuk mendeteksi adanya gangguan perkembangan pada anak, salah satunya adalah Capute Scales (cognitive adaptive test/clinical linguistic auditory milestone scale-CAT/ $C L A M S$ ), untuk menguji kemampuan komunikasi dan kognitif. Uji skrining spesifik metode Capute Scales (CAT/CLAMS) dapat digunakan untuk mendiagnosis adanya gangguan perkembangan bahasa dan fungsi kognitif pada usia 0-36 bulan. Metode uji tapis CAT/ CLAMS dipilih karena dapat menilai kuantifikasi developmental quotient (DQ) yang memberikan diagnosis banding gangguan perkembangan anak. ${ }^{6}$ Hasil dari pemeriksaan CAT/CLAMS digolongkan normal (DQ pada kemampuan bahasa dan visual motor $>85$, FSDQ $>85$ ), suspek (DQ pada satu atau kedua aspek 75-85), retardasi mental (DQ pada kemampuan bahasa dan visual motor menghasilkan $<75$ ), dan gangguan komunikasi (bila aspek bahasa terlambat tapi aspek visual motor dalam batas normal). ${ }^{7,8}$

Beberapa faktor diidentifikasi mempengaruhi perkembangan seorang anak, yaitu faktor genetik dan lingkungan seperti tingkat pendidikan orangtua, jenis kelamin, jumlah anak, dan bentuk keluarga. Tujuan penelitian untuk mengetahui perkembangan anak usia 0-36 bulan dan faktor-faktor yang berhubungan dengan perkembangan anak.

\section{Metode}

Desain penelitian yang digunakan adalah potong lintang, dilaksanakan pada tanggal 3-21 November 2008 di RW 03 Pulo Gadung, Jakarta Timur. Pengambilan data dilakukan dengan uji tapis perkembangan menggunakan metode CAT/CLAMS pada subjek dan pengisian kuesioner oleh peneliti yang ditanyakan kepada responden. Responden adalah ibu yang memiliki anak usia $0-36$ bulan beserta anaknya.

Kriteria inklusi penelitian adalah anak usia 0-3 tahun dan bertempat tinggal di tempat penelitian serta dalam keadaan mampu untuk menyelesaikan rangkaian pemeriksaan perkembangan. Kriteria penolakan apabila subjek memiliki kelainan kongenital dan atau genetik yang telah secara nyata menyebabkan keterlambatan perkembangan, dan responden menolak untuk mengikuti penelitian. Peserta dikeluarkan dari penelitian (dropout) bila subjek tidak berhasil mengikuti uji CAT/CLAMS serta responden tidak selesai mengisi kuesioner.

Peneliti mendapatkan daftar batita di setiap RT di RW 03 dari kantor Kelurahan Pulo Gadung, kemudian lalu dilakukan pengambilan sampel secara purposive. Peneliti bekerjasama dengan kader untuk mengumpulkan subjek yang diteliti. Secara bergiliran dilakukan uji tapis perkembangan dengan metode CAT/CLAMS serta dilakukan wawancara dengan responden. Analisis data dilakukan dengan menggunakan program SPSS for Windows versi 13.0. Pengujian data untuk mencari hubungan faktorfaktor menggunakan uji nonparametrik chi square dan Fisher.

\section{Hasil}

Jumlah batita di tempat penelitian 257, 79 anak diantaranya memenuhi kriteria inklusi, drop out 4 anak, sehingga jumlah subjek yang diteliti 75 anak. Pada Tabel 1 tertera distribusi subjek penelitian. Subjek dibagi dalam tiga kelompok umur, dengan jumlah subjek pada tiap kelompok hampir sama. Sebaran 
menurut jenis kelamin hampir seimbang dengan 57,3\% subjek berjenis kelamin laki-laki. Hampir seluruh $(93,3 \%)$ subjek memiliki berat lahir sama dengan atau lebih dari 2500 gram. Lebih dari setengah (56,0\%) subjek bukan merupakan anak pertama dan lebih banyak subjek yang tidak mendapat ASI eksklusif (62,7\%).

Pada Tabel 2 tertera karakteristik responden (ibu) penelitian. Responden paling banyak berusia antara $20-30$ tahun, 46 orang $(61,3 \%)$. Sebagian besar responden $(92,0 \%)$ mengandung subjek pada usia di bawah 35 tahun. Sejumlah 60 dari 75 responden memiliki jumlah anak kurang dari dua. Ditemukan

Tabel 1. Karakteristik anak

\begin{tabular}{lcc}
\hline Variabel & $\mathrm{N}$ & $\%$ \\
\hline Usia (tahun) & & \\
$0-<1$ & 25 & 33,3 \\
$1-<2$ & 29 & 38,7 \\
$2-<3$ & 21 & 28,0 \\
Jenis kelamin & & \\
$\quad$ Laki-laki & 43 & 57,3 \\
$\quad$ Perempuan & 32 & 42,7 \\
Berat lahir (gram) & & \\
$\quad<2500$ & 5 & 6,7 \\
$\quad 22500$ & 70 & 93,3 \\
Urutan anak & & \\
$\quad$ Anak pertama & 33 & 44,0 \\
$\quad$ Bukan anak pertama & 42 & 56,0 \\
Pemberian ASI eksklusif & & \\
$\quad$ Ya & 28 & 37,3 \\
$\quad$ Tidak & 47 & 62,7 \\
\hline
\end{tabular}

CLAMS

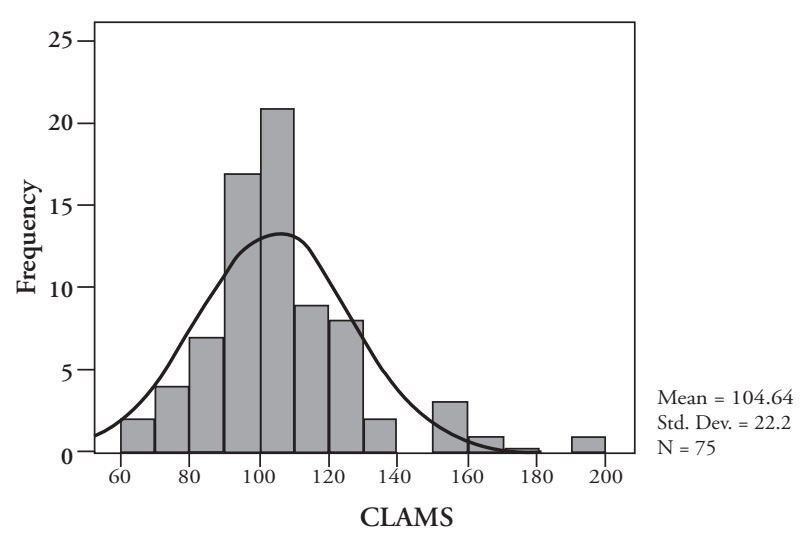

Gambar 1. Distribusi nilai CLAMS responden yang tidak bekerja atau sebagai ibu rumah tangga 55 orang $(73,3 \%)$. Responden umumnya memiliki tingkat pendidikan rendah, yaitu 41 orang $(54,7 \%)$. Bentuk keluarga yang terbanyak adalah keluarga inti (43 dari 75 responden).

Pada uji normalitas sebaran nilai CLAMS dan CAT subjek didapatkan sebaran yang tidak normal, baik

Tabel 2. Karakteristik ibu

\begin{tabular}{lcc}
\hline Variabel & $\mathrm{N}$ & $\%$ \\
\hline Usia (tahun) & 1 & 1,3 \\
$10-<20$ & 46 & 61,3 \\
$20-<30$ & 25 & 33,3 \\
$30-<40$ & 2 & 2,7 \\
$40-<50$ & 1 & 1,3 \\
$\quad 50-<60$ & 69 & \\
Usia saat hamil (tahun) & 62,0 \\
$\quad<35$ & & 8,0 \\
$\geq 35$ & 60 & 80,0 \\
Jumlah anak (orang) & 15 & 20,0 \\
$1-2$ & & \\
$\quad 2$ & 20 & 26,7 \\
Pekerjaan & 55 & 73,3 \\
Bekerja & & \\
Ibu rumah tangga & 34 & 45,3 \\
Tingkat pendidikan & 41 & 54,7 \\
$\quad$ Pendidikan tinggi & & \\
Pendidikan rendah & 43 & 57,3 \\
Bentuk keluarga & 28 & 37,3 \\
Keluarga inti & 4 & 5,3 \\
Keluarga majemuk & & \\
$\quad$ Keluarga extended &
\end{tabular}

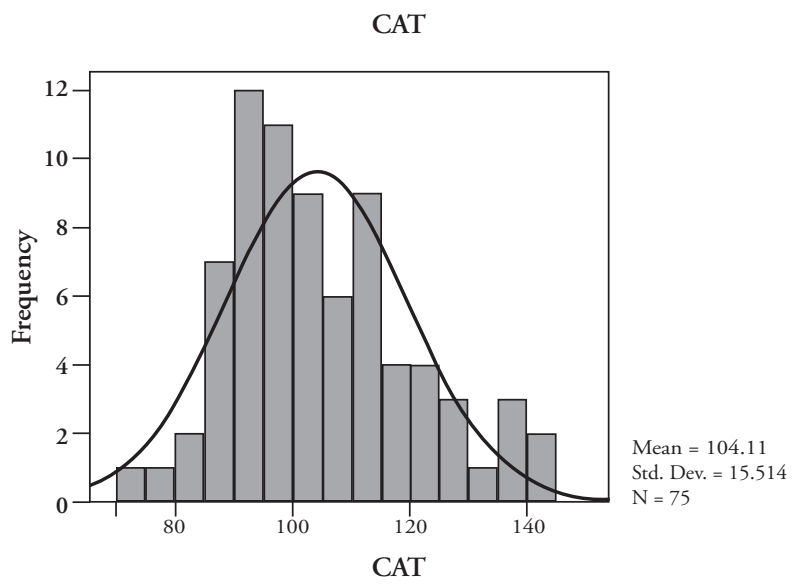

Gambar 2. Distribusi nilai CAT 
pada nilai CLAMS maupun nilai CAT. Didapatkan nilai tengah CLAMS 100,0 dan CAT 103,0 nilai bervariasi antara 60,0-200,0 untuk CLAMS dan 72,0142,0 untuk CAT.

Status perkembangan batita yang termasuk dalam batas normal $84 \%$, yaitu nilai CAT/CLAMS lebih dari atau sama dengan 85 . Subjek dengan suspek gangguan perkembangan (nilai CAT/CLAMS dari 75 hingga 84) $13,3 \%$. Jumlah subjek yang mengalami gangguan komunikasi, (nilai CLAMS kurang dari 75) 3,0\%. Tidak ditemukan subjek yang mengalami retardasi mental, (nilai CAT dan CLAMS kurang dari 75). Dari subjek dengan tersangka gangguan perkembangan $60 \%$ adalah tersangka mengalami gangguan bicara dan bahasa, sedangkan $40 \%$ tersangka menderita gangguan fungsi kognitif.

Pada Tabel 3 tertera hubungan antara faktorfaktor yang diteliti dengan status perkembangan anak. Setelah dilakukan uji statistik, tidak didapatkan adanya faktor yang bermakna berhubungan dengan status perkembangan subjek $(p<0,05)$.

\section{Pembahasan}

Dilaporkan hasil status perkembangan normal pada $84,0 \%$ subjek, dengan $3,0 \%$ mengalami gangguan komunikasi, dan sisanya $(13,3 \%)$ tersangka mengalami gangguan perkembangan. Persentase anak yang memiliki status perkembangan normal pada penelitian ini tidak berbeda jauh dengan penelitian lain yang dilakukan oleh Harahap di Jakarta Pusat tahun 2006 pada 149 bayi usia 3 hingga 24 bulan dengan menggunakan tiga metode untuk memeriksa status perkembangan anak. Dilaporkan $88,6 \%$ pada pemeriksaan dengan menggunakan metode Griffith mental developmental scales mempunyai status perkembangan normal, dengan metode Bayley 70,5\%, dan dengan uji tapis Denver II 75,9\%. ${ }^{10}$

Menurut distribusi subjek didapatkan hanya 37,3\% mendapat ASI eksklusif, hal ini merupakan suatu masalah karena ASI merupakan nutrisi yang esensial untuk bayi pada enam bulan pertama kehidupan. Hasil penelitian yang dilakukan di Biro

Tabel 3. Hubungan antara berbagai variabel bebas yang diteliti terhadap status perkembangan anak

\begin{tabular}{|c|c|c|c|c|}
\hline \multirow{2}{*}{ Faktor-faktor } & \multicolumn{3}{|c|}{ Status perkembangan anak, n (\%) } & \multirow{2}{*}{$p$} \\
\hline & Normal & Tersangka* & Gangguan komunikasi* & \\
\hline \multicolumn{5}{|l|}{ Jenis kelamin subjek } \\
\hline Perempuan & $28(88)$ & $3(9)$ & $1(3)$ & Chi-square \\
\hline Laki-laki & $34(79)$ & $7(16)$ & $2(5)$ & 0,340 \\
\hline \multicolumn{5}{|l|}{ Pemberian ASI eksklusif } \\
\hline $\mathrm{Ya}$ & $24(86)$ & $2(8)$ & $2(8)$ & Fisher \\
\hline Tidak & $38(81)$ & $8(17)$ & $1(2)$ & 0,756 \\
\hline \multicolumn{5}{|l|}{ Urutan anak } \\
\hline Anak pertama & $27(82)$ & $3(9)$ & $3(9)$ & Chi-square \\
\hline Bukan anak pertama & $35(83)$ & $7(17)$ & $0(0)$ & 0,863 \\
\hline \multicolumn{5}{|l|}{ Usia ibu saat hamil (tahun) } \\
\hline$<35$ & $56(81)$ & $10(14)$ & $3(4)$ & Fisher \\
\hline$\geq 35$ & $6(100)$ & $0(0)$ & $0(0)$ & 0,582 \\
\hline \multicolumn{5}{|l|}{ Pendidikan ibu/pengasuh } \\
\hline Pendidikan tinggi & $26(75)$ & $7(21)$ & $1(3)$ & Chi-square \\
\hline Pendidikan rendah & $36(88)$ & $3(7)$ & $2(5)$ & 0,489 \\
\hline \multicolumn{5}{|l|}{ Jumlah anak (orang) } \\
\hline $1-2$ & $51(85)$ & $6(10)$ & $3(5)$ & Fisher \\
\hline$>2$ & $11(73)$ & $4(27)$ & $0(0)$ & 0,279 \\
\hline \multicolumn{5}{|l|}{ Bentuk keluarga } \\
\hline Keluarga inti & $35(83)$ & $6(14)$ & $2(5)$ & Chi-square \\
\hline Keluarga majemuk/extended & $28(84)$ & $3(9)$ & $1(3)$ & 0,738 \\
\hline
\end{tabular}

* dalam uji statistik digabungkan 
Konsultasi Anak di Rumah Sakit UGM Yogyakarta tahun 1976 menunjukkan bahwa anak yang mendapat air susu ibu sampai umur satu tahun 50,6\%. Laporan Survei Demografi Kesehatan Indonesia (SKDI) tahun 1994 menunjukkan bahwa ibu yang memberikan ASI eksklusif kepada bayinya $47,0 \%$, sedangkan pada REPELITA IV ditargetkan 80,0\%. Alasan yang dikemukakan oleh ibu mengapa keliru dalam pemanfaatan ASI eksklusif pada bayinya antara lain karena produksi ASI kurang, kesulitan dalam menghisap, keadaan puting susu ibu yang tidak menunjang, ibu bekerja, keinginan untuk disebut sebagai ibu modern, dan pengaruh iklan/promosi pengganti ASI.

Secara statistik tidak didapatkan hubungan antara jenis kelamin dengan status perkembangan namun terlihat bahwa laki-laki memiliki kecenderungan lebih besar mempunyai status perkembangan yang tidak normal $(21 \%)$ dibandingkan dengan perempuan (12\%). Hal ini sesuai dengan penelitian yang dilakukan Sinto dkk, ${ }^{4}$ dan teori yang menyatakan bahwa anak laki-laki lebih sering sakit sehingga dapat menyebabkan kemungkinan terjadinya gangguan perkembangan, walaupun keterangan tersebut belum diketahui secara pasti.

Tidak ditemukan hubungan antara pemberian ASI eksklusif dengan status perkembangan, meskipun demikian terlihat bahwa persentase subjek dengan status perkembangan tidak normal lebih besar pada kelompok yang tidak mendapat ASI eksklusif dibandingkan kelompok yang mendapat ASI eksklusif (19\% dibanding 16\%). Hasil serupa juga didapatkan dari hasil penelitian Sacker, yang melaporkan bahwa ASI merupakan faktor protektif terhadap terjadinya gangguan perkembangan, ${ }^{11}$ Peneliti lain juga menyebutkan fungsi kognitif pada anak yang mendapat ASI eksklusif lebih baik dari yang tidak mendapat. ${ }^{12}$ ASI merupakan nutrisi alamiah yang paling tepat untuk bayi, mudah dicerna, memiliki komposisi zat gizi yang ideal sesuai dengan kebutuhan dan kemampuan pencernaan bayi. Disamping itu ASI mengandung laktulosa dan antibodi yang berfungsi melindungi bayi dari infeksi, dan proses pemberian ASI dapat menjalin hubungan yang lebih erat antara ibu dan bayi. Secara alamiah terjadi kontak kulit yang bermanfaat bagi perkembangan psikis dan emosional antara ibu dan anak.

Persentase antara anak pertama dan bukan anak pertama yang mempunyai status perkembangan tidak normal hampir sama. Subjek yang lahir dari ibu yang berusia di bawah 35 tahun tampak lebih banyak yang menderita status perkembangan yang tidak normal. Hasil ini berbeda dengan teori yang menyebutkan bahwa kelahiran dengan usia ibu di atas 35 tahun memiliki risiko untuk melahirkan anak dengan sindrom sehingga kemungkinan untuk menderita status perkembangan yang tidak normal lebih besar. ${ }^{13}$ Hal tersebut dapat terjadi pada penelitian kami karena jumlah ibu yang melahirkan anak sama dengan atau diatas 35 tahun hanya berjumlah enam orang.

Ibu dengan tingkat pendidikan tinggi cenderung memiliki persentase lebih tinggi terhadap status perkembangan tidak normal pada anak. Hasil yang berbeda didapatkan dari penelitian Sinto $\mathrm{dkk}^{4}$ kemungkinan disebabkan ibu dengan tingkat pendidikan tinggi pada umumnya bekerja sehingga perhatian yang diberikan kepada anak lebih sedikit daripada ibu yang tidak bekerja.

Responden dengan jumlah anak lebih dari dua mempunyai kecenderungan menderita status perkembangan yang tidak normal seperti halnya pada penelitian Sinto $\mathrm{dkk}^{4}$ dapat disebabkan pada keluarga yang memiliki jumlah anak lebih dari dua, maka perhatian keluarga tidak begitu besar memperhatikan tumbuh kembang anaknya.

Hubungan antara bentuk keluarga dengan status perkembangan, cenderung angka kejadian status perkembangan tidak normal pada subjek dengan tipe keluarga inti. Pada keluarga dengan bentuk keluarga majemuk atau extended jumlah anggota keluarga umumnya lebih banyak sehingga stimulasi terhadap subjek lebih banyak.

\section{Kesimpulan}

Disimpulkan bahwa $84,0 \%$ dari anak usia 0-36 bulan yang bertempat tinggal di RW 03 kelurahan Pulo Gadung Jakarta Timur mempunyai status perkembangan normal. Gangguan komunikasi terdapat pada 3\% dan gangguan perkembangan 13,3\% dari 75 orang anak yang ikut dalam penelitian. Jenis kelamin laki-laki, tidak mendapat ASI eksklusif, ibu dengan tingkat pendidikan tinggi, jumlah anak lebih dari dua, dan bentuk keluarga inti mempunyai kecenderungan lebih besar menderita status perkembangan yang tidak normal. Tidak didapatkan hubungan yang bermakna secara statistik antara faktor-faktor yang diteliti dengan status perkembangan anak. 


\section{Daftar Pustaka}

1. Departemen Kesehatan RI. Pedoman pelaksanaan stimulasi, deteksi dan intervensi dini tumbuh kembang anak ditingkat pelayanan kesehatan dasar. Jakarta: Departemen Kesehatan RI, 2006.h.4-14.

2. Tanuwidjaya S. Konsep umum tumbuh dan kembang. Dalam: Narendra MB, Sularyo TS, Soetjiningsih, Suyitno H, Gde Ranuh IGN, penyunting. Tumbuh kembang anak dan remaja. Edisi ke-1. Jakarta: Sagung Seto; 2002.h.1-12.

3. Sudjatmiko. Deteksi dini gangguan tumbuh kembang balita. Sari Pediatri 2001;3:175-88.

4. Sinto R, Oktaria S, Astuti SL, Mirdhatillah S, Sekartini R, Wawolumaya C. Penapisan perkembangan anak usia 6 bulan-3 tahun dengan uji tapis perkembangan Denver II. Sari Pediatri 2008;9:348-53.

5. Kadi FA, Garna H, Fadlyana E. Kesetaraan hasil skrining risiko penyimpangan perkembangan menurut cara kuesioner praskrining perkembangan (KPSP) dan denver II pada anak usia 12-14 bulan dengan berat lahir rendah. Sari Pediatri 2008;10:29-33.

6. Leppert MLO. Development of the capute scales. Accardo PJ, Capute AJ. The capute scales: cognitive adaptive test/clinical linguistic \& auditory milestone scale. Baltimore: Paul H. Brookes Publishing Co; 2005.h.1-8.
7. Leppert MLO. The Capute Scales: Administration and scoring. Accardo PJ, Capute AJ. The capute scales: cognitive adaptive test/ clinical linguistic \& auditory milestone scale. Baltimore: Paul H. Brookes Publishing Co; 2005.h.9-29.

8. Dhamayanti M, Herlina M. Skrining gangguan kognitif dan bahasa dengan capute scales (cognitive adaptive test/clinical linguistic \& auditory milestone scale-CAT/CLAMS). Fakultas Kedokteran Universitas Padjadjaran; 2007.

9. Kube DA, Wilson WM, Petersen MC, Palmer FB. CAT/ CLAMS.: its use in detecting early childhood cognitive impairment. Pediatric neurology 2000;23:208-15.

10. Harahap REG. Perbandingan uji tapis bayley infant neurodevelopment screener (BINS) dengan uji tapis denver II untuk deteksi dini keterlambatan perkembangan bayi usia 3-24 bulan dengan menggunakan baku emas griffiths mental development scales. Tesis. Fakultas Kedokteran Universitas Indonesia;2006.

11. Sacher A, Quigky MA, Kelly YJ. Breastfeeding and developmental delay: findings from millenium cohort study. Pediatric. 2006;118;e682-9.

12. Novita L, Gurnida DA, Garna H. Perbandingan fungsi kognitif bayi usia 6 bulan yang mendapat dan yang tidak mendapat asi eksklusif. Sari Pediatri 2008;9:429-34.

13. Kadri, N. Kelainan kongenital. Dalam: Wiknjosatro $H$, Saifuddin AB, Rachimhadhi T, penyunting. Ilmu kebidanan Edisi Ketiga. Jakarta: Yayasan Bina Pustaka Sarwono Prawirohardjo; 2006.h.725-6. 